WoJCIECH DYBA

Uniwersytet im. Adama Mickiewicza w Poznaniu, Polska

Adam Mickiewicz University, Poznań, Poland

TADEUSZ STRYJAKIEWICZ

Uniwersytet im. Adama Mickiewicza w Poznaniu, Polska

Adam Mickiewicz University, Poznań, Poland

\title{
Źródła wiedzy w różnych fazach cyklu życia klastra: przykłady $z$ branży meblarskiej we Włoszech i w Polsce
}

\section{Sources of Knowledge in Different Stages of a Cluster Life Cycle: the Examples of Furniture Industry in Italy and Poland}

\begin{abstract}
Streszczenie: Klastry - przestrzenne koncentracje powiązanych ze sobą przedsiębiorstw i instytucji w wybranych branżach gospodarczych - znane są w literaturze jako miejsca umożliwiające tworzenie i rozpowszechnianie specjalistycznej wiedzy. Artykuł przedstawia wyniki badania porównawczego dotyczącego źródeł wiedzy dla firm na obszarze dwóch klastrów meblarskich znajdujących się w różnych fazach cyklu życia, określanych na podstawie wskaźników zatrudnienia, produkcji i eksportu. Pierwszym analizowanym przykładem jest klaster w Livenzie, położony na obszarze tzw. Trzecich Włoch, należący do dojrzałych, drugim - kępińskie zagłębie meblowe, które można zaklasyfikować jako klaster w fazie wzrostu. Badania ankietowe przeprowadzone w przedsiębiorstwach działających na tych obszarach pozwoliły wykazać, że firmy w klastrze dojrzałym - w zestawieniu z firmami w klastrze rosnącym - wykorzystują więcej różnorodnych i profesjonalnych źródeł wiedzy, takich jak: 1) firmy konsultingowe, 2) zatrudnianie nowych pracowników wnoszących do firmy aktualną wiedzę branżową, 3) szkolenia i działania instytucji publicznych. Wyniki te mogą stanowić wytyczną dla instytucji otoczenia biznesu oraz władz regionalnych na temat wspierania najbardziej pożądanych przez lokalne firmy klastrowe sposobów pozyskiwania nowej wiedzy.
\end{abstract}

\begin{abstract}
Clusters - spatial concentrations of companies and institutions in functionally-related fields - are known as places facilitating the creation and spreading of knowledge. Facing competition from similar firms nearby, cluster firms must constantly search for and utilise new technological and business knowledge. In this paper we present the results of a comparative study conducted in the companies located within two furniture clusters operating in different life cycle stages, which have been determined on the basis of employment, production and export indicators. The first cluster - Livenza is located in the North of Italy and is an example of a mature cluster, the second - in Kępno (Greater Poland region) - as a growing one. Questionnaire survey of the firms located in these areas allowed to state that the firms in the first cluster - in relation to the second one - use more professional knowledge sources, such as: consulting firms, employing "knowledge agents" delivering current knowledge expertise, trainings and actions of public institutions. The results of the study may become a guideline for business environment institutions and public authorities as to the ways of obtaining new, external knowledge which is most expected by the local cluster firms.
\end{abstract}

Słowa kluczowe: branża meblarska; cykl życia klastra; klaster; źródła wiedzy Keywords: cluster; cluster life cycle; furniture industry; knowledge sources 
Otrzymano: 27 marca 2019

Received: 27 March 2019

Zaakceptowano: 11 lipca 2019

Accepted: 11 July 2019

Sugerowana cytacja / Suggested citation:

Dyba, W., Stryjakiewicz, T. (2019). Źródła wiedzy w różnych fazach cyklu życia klastra: przykłady z branży meblarskiej we Włoszech i w Polsce. Prace Komisji Geografii Przemysłu Polskiego Towarzystwa Geograficznego, 33(4), 26-41. doi: 10.24917/20801653.334.2

\section{WSTĘP}

Ciągłe tworzenie i zdobywanie nowej wiedzy to elementy niezbędne do rozwoju firmy i jej adaptacji do zmieniających się warunków rynkowych. Pozyskiwanie wiedzy to pierwszy i podstawowy element większości modeli zarządzania wiedzą w przedsiębiorstwie (Wiig, 1997; Probst, Raub, Romhardt, 2000; Bukowitz, Williams, 2000). Możliwości pozyskiwania wiedzy nie są jednakże wszędzie takie same: niektóre miejsca stwarzają dodatkowe szanse na poszukiwanie, znajdowanie i wykorzystywanie zewnętrznej wiedzy. Klastry, stanowiąc koncentracje przestrzenne powiązanych ze sobą przedsiębiorstw i instytucji w wybranej branży gospodarczej - to obszary uznawane za miejsca, które stwarzają szczególnie korzystne warunki do przepływów wiedzy pomiędzy firmami i instytucjami (Swann, 2009; Camuffo, Grandinetti, 2011). Właściwości klastrów, w tym również te, które warunkują tworzenie i rozwijanie wiedzy, zmieniają się wraz ze wzrostem liczby firm i instytucji w klastrze, a także liczby powiązań między nimi - są więc ściśle związane ze ścieżką cyklu życia klastra (Porter, 1990; Bergman, 2008; Fornahl, Hassink, Menzel, 2015).

W artykule przedstawione są wyniki badań nad pozyskiwaniem zewnętrznej wiedzy przez menedżerów i właścicieli firm położonych na obszarze klastrów będących w różnych fazach cyklu życia. Celem tych badań była próba odpowiedzi na pytanie, w jaki sposób klaster umożliwia firmom pozyskiwanie i wykorzystywanie nowej, zewnętrznej wiedzy istotnej dla ich funkcjonowania i rozwoju. W szczególności analizowana była hipoteza, że w dojrzałym klastrze firmy częściej korzystają z profesjonalnych źródeł wiedzy niż firmy w klastrach znajdujących się w początkowej lub wzrostowej fazie cyklu życia.

Do badania empirycznego wybrane zostały dwa europejskie klastry meblarskie o podobnej wielkości (mierzonej liczbą przedsiębiorstw i zatrudnienia), lecz różniące się od siebie historią, a przez to obecną fazą tzw. cyklu życia. Pierwszy klaster meblarski z Livenzy zlokalizowany jest w okolicy Treviso i Pordenone, we włoskich regionach Wenecja Euganejska i Friuli-Wenecja Julijska. Klaster ten określić można jako dojrzały, w którym wiele firm o uznanej pozycji szuka sobie nowych ścieżek rozwoju. Drugi klaster meblarski, położony w okolicy Kępna w Wielkopolsce - to klaster, który zakwalifikować można jako rosnący, w ostatnich latach zwiększający zatrudnienie, a także wielkość produkcji i eksportu. Lokalizację obu klastrów przedstawia rycina 1. 
Rycina 1. Lokalizacja analizowanych klastrów na tle europejskich regionów o ponadprzeciętnym zatrudnieniu w sektorze meblarstwa

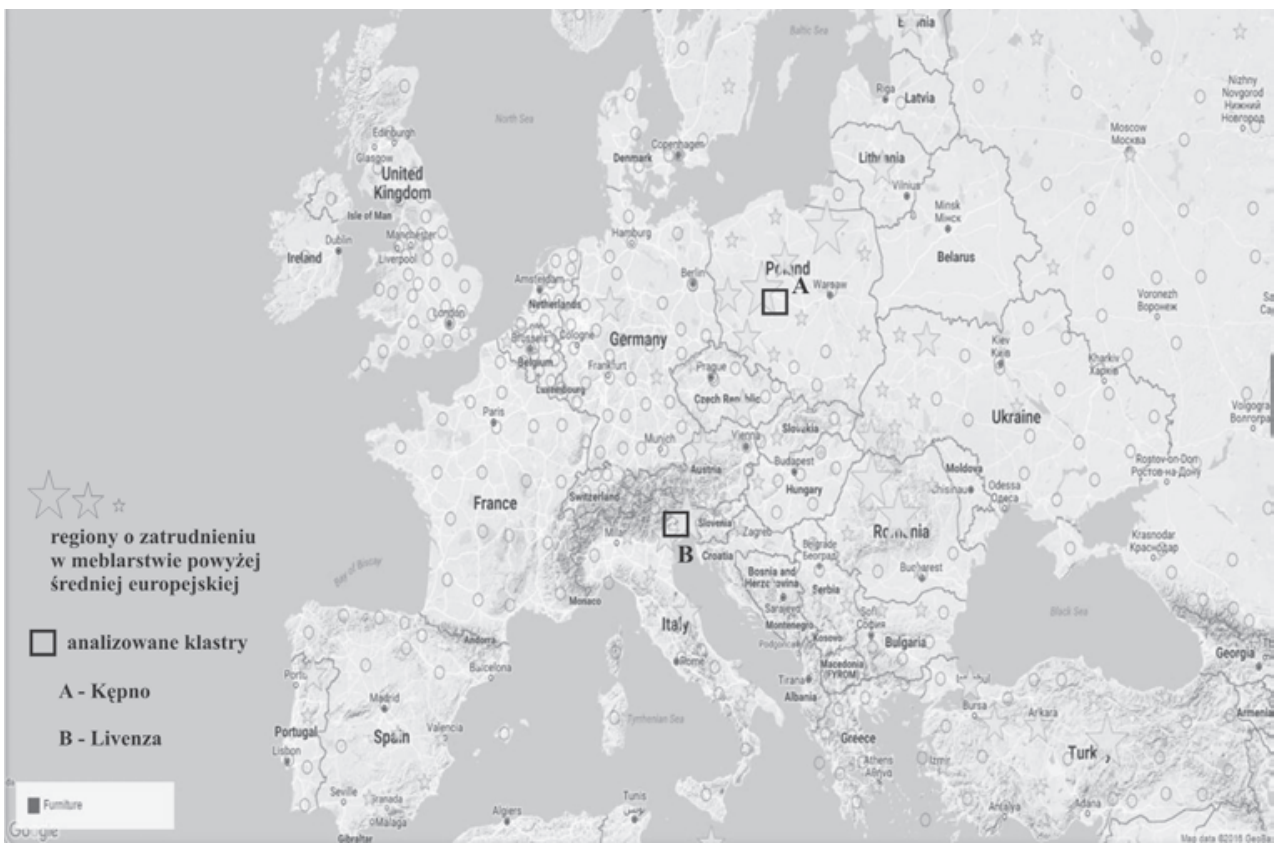

Objaśnienie: zatrudnienie w meblarstwie większe niż średnia europejska - oznaczone gwiazdkami - obliczone zostało z wykorzystaniem ilorazu lokalizacji - proporcji liczby pracujących w meblarstwie w regionie do całkowitego zatrudnienia w tym regionie, przez liczbę zatrudnionych w meblarstwie w Europie w stosunku do całkowitego zatrudnienia w Europie.

Źródło: Cluster Observatory (2018)

\section{POZYSKIWANIE WIEDZY JAKO ELEMENT ZARZĄDZANIA WIEDZĄ W PRZEDSIĘBIORSTWACH}

Wiedza z punktu widzenia przedsiębiorstw może być rozumiana jako informacje i umiejętności wykorzystywane do wyjaśniania, racjonalnego działania, podejmowania decyzji i rozwiązywania problemów w bieżącym funkcjonowaniu tych przedsiębiorstw (Probst, Raub, Romhardt, 2000). Tworzenie, rozpowszechnianie i wykorzystywanie wiedzy jest podstawą rozwoju państw, regionów i firm - stąd jest to podstawowy element koncepcji gospodarki opartej na wiedzy (Toffler, 1990; OECD, 1996; Kukliński, 2001; Chojnicki, Czyż, 2006; Toffler, 2006) oraz przedsiębiorstwa opartego na wiedzy (Grant, 2002; Kogut, Zander, 1992). Na poziomie mikroekonomicznym wszystkie procesy umożliwiające tworzenie, rozpowszechnianie i wykorzystywanie wiedzy, aby realizować cele organizacji, określa się mianem zarządzania wiedzą (Davenport, Prusak, 1998; Jemielniak, Koźmiński, 2008). Tworzenie wiedzy jest uważane za pierwszy i najważniejszy z wyżej wymienionych trzech elementów. Z jednej strony jest to zachęcanie pracowników firmy do wykorzystywania własnego doświadczenia i umiejętności w celu rozwijania wiedzy wewnątrz firmy. Z drugiej strony zarządzanie wiedzą koncentruje się na sposobach pozyskiwania zewnętrznej wiedzy, a więc na poszukiwaniu i zdobywaniu potrzebnych informacji ze źródeł znajdujących się poza firmą. 
W modelu zarządzania wiedzą W.R. Bukowitza i R.L. Williamsa (2000) punktem wyjścia jest pozyskiwanie wiedzy z otoczenia firmy, po którym następuje wykorzystywanie tej wiedzy, szacowanie jej zasobów, utrzymywanie i rozwijanie owych zasobów i wreszcie sprzedaż wiedzy w formie nowych produktów, usług i technologii. Z kolei w modelu zarządzania wiedzą sformułowanym przez G.J.B. Probsta, S. Rauba i K. Romhardta (2000), dwa pierwsze etapy to identyfikacja wiedzy i pozyskiwanie wiedzy. Procesy te wynikają z ustalania celów strategicznych w zakresie wiedzy przez osoby zarządzające firmą i są postrzegane jako początkowe i konieczne etapy dalszego rozwijania wiedzy, dzielenia się nią, rozpowszechniania jej, wykorzystywania i zachowywania. Skuteczne pozyskanie wiedzy ze źródeł zewnętrznych jest podstawowym elementem organizacji uczącej się - rozwijania wiedzy wewnątrz tej organizacji poprzez przekształcanie, łączenie i kombinowanie zasobów wiedzy (Nonaka, 1994; Perechuda, 1998). Do źródeł wiedzy zewnętrznej dla firm - bez względu na ich lokalizację i specyfikę reprezentowanej branży - zaliczyć można profesjonalną współpracę badawczą $\mathrm{z}$ różnymi podmiotami gospodarczymi, zakup wiedzy na zasadach rynkowych, a także nieformalne kontakty (Kang, Kang, 2009). Klastry jako szczególne zgrupowania podobnych firm w przestrzeni część tych źródeł czynią jeszcze bardziej dostępnymi, a ponadto stwarzają dodatkowe możliwości pozyskiwania wiedzy z zewnątrz.

\section{POZYSKIWANIE I PRZEPŁYWY WIEDZY W KLASTRACH}

Klastry określane są jako przestrzenne koncentracje powiązanych ze sobą firm (produkujących dobra finalne, poddostawców, dostarczycieli usług) i instytucji w wybranej branży (Porter, 1990, 1998; Gorynia, Jankowska, 2008). Podobną koncepcję, historycznie wcześniejszą, bo sięgającą do prac A. Marshalla (1890), stanowią okręgi przemysłowe (zwane też dystryktami przemysłowymi), spopularyzowane w szczególności w odniesieniu do Trzecich Włoch (Pyke, Becattini, Sengenberger, 1990; Becattini, Bellandi, De Propris, 2009). Zgodnie z nią pewna grupa firm (głównie małych i średnich), specjalizujących się w wybranej branży i położonych na pewnym ograniczonym obszarze, połączona jest zależnościami, a produkcja i struktury społeczne przenikają się wzajemnie (De Marchi, Grandinetti, 2014). Jakkolwiek trwa debata nad subtelnymi różnicami pomiędzy tymi pojęciami (F.J. Ortega-Colomer, F.X. Molina-Morales, I. Fernandez de Lucio, 2016, M.E. Porter i C Ketels, 2009, uznają pojęcie klastra za szersze), w badaniach empirycznych mogą one być - i są również w niniejszym artykule - traktowane jako synonimy.

Bliskość geograficzna w powiązaniu z podobną wyspecjalizowaną działalnością firm w klastrach stwarzają możliwości uczenia się oraz zarówno celowych, jak i nieplanowanych przepływów wiedzy (Porter, 1998; Maskell, Malmberg, 2007; Dyba, 2016). H. Bathelt, A. Malmberg i P. Maskell (2004), przedstawiając model tworzenia i rozpowszechniania wiedzy w klastrze, stwierdzają, że firmy o podobnych wartościach, postawach i sposobach postępowania tworzą warunki dla „lokalnego gwaru” (ang. local buzz) - nieformalnej wymiany wiedzy. Jednocześnie jednak w klastrze zachodzi konieczność tworzenia "globalnych kanałów transportujących wiedzę" (ang. global pipelines, w dosłownym tłumaczeniu - globalne rurociągi), ze źródłami wiedzy znajdującymi się poza najbliższym otoczeniem regionalnym, w którym klaster funkcjonuje. Tylko współwystępowanie tych dwóch kanałów rozpowszechniania wiedzy może zapewnić firmom z klastra przewagę niedostępną dla podmiotów z zewnątrz (Giuliani, 2007). 
Zewnętrzne relacje z dostawcami, klientami, instytucjami badawczymi czy marketingowymi - poprzez włączenie ich w globalne łańcuchy wartości - mogą znacząco podnieść potencjał klastra lub firm klastrowych (De Marchi, Di Maria, Gereffi, 2017). Zasoby wiedzy powstałe w wyniku lokalnych i odległych powiązań tworzą z klastrów otwarte systemy uczenia się. Łączenie starych i nowych zasobów wiedzy przynosi korzyści zarówno firmom klastrowym, jak i ich otoczeniu, a w konsekwencji obszarom, na których działają (Belussi, Sedita, 2012).

Przepływy wiedzy w klastrach stanowiły przedmiot badań wielu badań - szczególnie w USA i krajach Europy Zachodniej. M. Trippl, F. Tödtling i L. Lengauer (2009) dzielą zewnętrzne źródła wiedzy w klastrze na formalne - rynkowe, oparte na zakupach lub współpracy, i nieformalne - rozlewanie się wiedzy i kontakty osobiste, które dodatkowo dzielą się na statyczne (transfer wiedzy) i dynamiczne (wspólne uczenie się). M.P. Menzel i D. Fornahl (2010) oraz R. Martin i J. Moodysson (2011) za najważniejsze źródła wiedzy w klastrach uznają: a) monitoring (na targach, poprzez ankiety, magazyny i czasopisma); b) mobilność pracowników (z wyszczególnieniem tego samego sektora, uniwersytetów, szkół wyższych i innych sektorów) oraz c) współpracę (z jednostkami naukowo-badawczymi i innymi firmami). Wreszcie A. Camuffo i R. Grandinetti (2011) na podstawie przeglądu literatury wyróżniają cztery główne mechanizmy transferu wiedzy pomiędzy firmami, specyficzne dla włoskich klastrów w tradycyjnych sektorach wytwórczości: a) relacje międzyorganizacyjne i interpersonalne, b) obserwacja nastawiona na imitację innych, c) przemieszczanie się osób z jednej istniejącej firmy do innej oraz d) tworzenie nowych przedsiębiorstw (ang. spin offs) i związane z nim pozyskiwanie zasobów ludzkich wraz z zasobami ich wiedzy. Sporą popularność w literaturze zyskały badania relacji między podmiotami w klastrze: niektórzy autorzy podkreślają, że klastry stwarzają dodatkowe możliwości w zakresie przepływów wiedzy, nie tylko jawnej, ale też ukrytej (ang. tacit knowledge, Storper, Venables, 2004). Zjawisko to jest szczególnie widoczne w klastrach innowacyjnych w sektorach hi-tech, np. ICT czy biotechnologii (Tsai, 2006; Swann, 2009). Elementem umożliwiającym przepływy wiedzy pomiędzy podmiotami w klastrze jest bliskość nie tylko geograficzna (przestrzenna), lecz również poznawcza, organizacyjna, społeczna i instytucjonalna (Boschma, Ter Wal, 2007). Procesy te zależą również od dominującego rodzaju wiedzy, na której działalność opierają firmy w klastrze, np. w podziale na wiedzę symboliczną, syntetyczną oraz analityczną; inne też są możliwości pozyskiwania wiedzy technologicznej i rynkowej (Martin, Moodysson, 2011). Badania prowadzone w polskich klastrach i organizacjach klastrowych pokazują, że bliskość geograficzna przedsiębiorstw i instytucji sprzyja przepływom wiedzy, lecz wykorzystywane źródła nowej wiedzy i ich kanały zależą m.in. od poziomu zaawansowania technologicznego branży klastra oraz stopnia sformalizowania współpracy (Dyba, 2016; Micek, 2017).

\section{WIEDZA A CYKL żYCIA KLASTRÓW}

Klastry i ich cechy charakterystyczne zmieniają się w miarę upływu czasu. Koncepcja cyklu życia klastra nawiązuje do koncepcji cyklu życia produktu R. Vernona (1966) i ściśle wiąże się z fazami cyklu życia przemysłu wprowadzonymi do dyskursu naukowego w kontekście międzynarodowej konkurencyjności przez W.J. Abernathy'ego i J.M. Utterbacka (1978) oraz M. Portera (1980). Cykl życia klastra oznacza, że przechodzi on przez fazy: pojawienia się (początku), wzrostu i dojrzałości, po której następuje 
albo spadek wynikający z uwięzienia na ścieżce rozwoju (ang. lock-in), stagnacja, albo też odnowienie i zapoczątkowanie nowej fazy wzrostu (Porter, 1990; Maskell, Kebir, 2005; Bergman, 2008; Fornahl, Hassink, Menzel, 2015). Niektórzy autorzy analizowali cechy związane z czynnikami sektorowymi lub odnoszącymi się bezpośrednio do klastra i jego otoczenia, które wpływają na przechodzenie przez poszczególne fazy cyklu życia (Maskell, Malmberg, 2007; Menzel, Fornahl, 2010). Zdaniem D. Fornahla, R. Hassinka i M.P. Menzela (2015) ewolucję klastrów należy wyjaśniać poprzez aktorów, sieci oraz instytucje, których zmiany funkcjonowania powodują przechodzenie do kolejnych faz rozwoju klastra. Jednocześnie określanie faz cyklu życia klastra nie zawsze jest proste, gdyż trajektorie rozwojowe klastrów są często złożone i wieloaspektowe. Według R. Martina i P. Sunleya (2011) klastry to ciągle adaptujące się systemy, stale dostosowujące się do warunków zewnętrznych.

M.P. Menzel i D. Fornahl (2010) dowodzą, że im bardziej dojrzały klaster, tym większe są zarówno jego wymiary ilościowe (wielkość mierzona liczbą przedsiębiorstw, aktorów/interesariuszy, pracowników itp.), jak i wymiary jakościowe (tj. różnorodność w zakresie wiedzy, kompetencji i form organizacyjnych). Zmieniają się również wymiary i możliwości systemowe: zarówno korzyści skali (economies of scale) - zdolności do działania wspólnego, jak i korzyści różnorodności (economies of scope) - przejawiające się w eksploatacji synergii i sieciowych zależności pomiędzy konkurentami a ich otoczeniem instytucjonalnym. Wraz ze zmieniającym się klastrem zmienia się jego charakterystyka w zakresie wiedzy. W początkowym stadium rozwoju wiedza ma charakter zróżnicowany, niejednorodny; rzadkie są również relacje między firmami a instytucjami mogące prowadzić do przepływów wiedzy. Wraz z pojawianiem się nowych firm klastrowych, często naśladujących firmy pionierskie, zasoby lokalnej wiedzy ulegają poszerzeniu. Jest to możliwe poprzez dzielenie się wiedzą oraz dopływy wiedzy zewnętrznej, spoza klastra (Li, 2018). Badania E.M. Bergmana (2008) i R.R. Stougha (2015) dowodzą, że dopiero dojrzałe klastry charakteryzują się bazą wiedzy naukowej, która umożliwia przedsiębiorstwom współpracę z uniwersytetami i centrami badawczymi. Wiedza w późniejszych fazach cyklu życia staje się bardziej jednorodna, pełna i zrozumiała przez wszystkich interesariuszy klastra (tabela 1).

Tabela 1. Wiedza w fazach cyklu życia klastra (od stadium początkowego do dojrzałości)

\begin{tabular}{|l|l|l|l|}
\hline & \multicolumn{1}{|c|}{ Początek } & \multicolumn{1}{c|}{ Wzrost } & \multicolumn{1}{c|}{ Dojrzałość } \\
\hline $\begin{array}{l}\text { Główni aktorzy tworzenia } \\
\text { i rozpowszechniania } \\
\text { wiedzy }\end{array}$ & $\begin{array}{l}\text { Pionierzy i firmy } \\
\text { wiodące }\end{array}$ & $\begin{array}{l}\text { Firmy - naśladowcy, } \\
\text { pierwsze instytucje } \\
\text { wspierające }\end{array}$ & $\begin{array}{l}\text { Aktywna rola } \\
\text { instytucji i organizacji } \\
\text { badawczych oraz } \\
\text { uniwersytetów }\end{array}$ \\
\hline Charakterystyka wiedzy & Heterogeniczność & $\begin{array}{l}\text { Zasoby wiedzy rosną } \\
\text { i są coraz częściej } \\
\text { wykorzystywane przez } \\
\text { interesariuszy }\end{array}$ & $\begin{array}{l}\text { Homogeniczność, } \\
\text { wiedza powszechnie } \\
\text { znana i dostępna }\end{array}$ \\
\hline $\begin{array}{l}\text { Sieci wiedzy pomiędzy } \\
\text { firmami a instytucjami }\end{array}$ & Rzadkie i niestabilne & $\begin{array}{l}\text { Rośnie liczba i gęstość } \\
\text { sieci (tj. liczba relacji) }\end{array}$ & Powszechne \\
\hline
\end{tabular}

Źródło: opracowanie na podstawie Bergman (2008), Menzel, Fornahl (2010), Stough (2015)

W dojrzałych klastrach nasila się pewna specyficzna zależność pomiędzy firmami - jednoczesna współpraca i konkurencja (określana jako koopetycja - od angielskich słów cooperation i competition: You, Wilkinson, 1994; Jankowska, 2012). Rozszerzając 
rozumowanie oparte na koncepcji cyklu życia przemysłu (Audretsch, Feldman, 1996), wydaje się, że pozytywne efekty aglomeracji widoczne w początkowych fazach cyklu życia klastra mogą przerodzić się w niekorzyści zbyt dużej koncentracji firm. Konkurencja staje się silniejsza, a wiedza coraz bardziej powszechna, dostępna i homogeniczna. Ujawnienie wiedzy innym firmom w dowolnej formie może spowodować utratę przewagi konkurencyjnej (Schrader, 1991), co jeszcze silniej uwidacznia się w warunkach kryzysu gospodarczego - jak np. po 2010 roku, gdy firmy klastrowe były mniej skłonne do jakiejkolwiek formalnej lub nieformalnej współpracy (Hoffmann, Belussi, Martínez-Fernández, Reyes, 2017). W takich warunkach konieczna jest ochrona posiadanych zasobów wiedzy firmy, a jednocześnie poszukiwanie różnorodnych specjalistycznych źródeł wiedzy - i często płacenie za te, które zapewnią firmie przewagę konkurencyjną. Na tej podstawie została sformułowana hipoteza badawcza: kierownictwo firm przypisuje większe znaczenie profesjonalnym źródłom wiedzy w dojrzałym klastrze niż w początkowych i wzrostowych fazach cyklu życia klastra.

\section{STUDIA PRZYPADKU I METODY BADAWCZE}

Wybrane do analizy klastry znajdują się we Włoszech i w Polsce - dwóch krajach znajdujących się wśród czołowych producentów i eksporterów mebli na świecie. W 2017 roku kraje te zajmowały odpowiednio czwartą i szóstą pozycję wśród producentów mebli (za Chinami, USA, Niemcami i Indiami na piątym miejscu) oraz czwartą i trzecią lokatę wśród eksporterów mebli (za Chinami i Niemcami). Klaster włoski to Livenza koncentracja firm związanych z branżą meblarską w regionach Wenecja Euganejska i Friuli-Wenecja Julijska (w okolicy Treviso i Pordenone); klaster w Polsce to kępińskie zagłębie meblowe (klaster w Kępnie), obejmujące powiaty kępiński, ostrzeszowski, oleśnicki i wieruszowski położone na styku województw wielkopolskiego, dolnośląskiego i łódzkiego (tabela 2). Są to dwie największe i najważniejsze koncentracje przestrzenne firm meblarskich w obu krajach (Buciuni, Corò, Micelli, 2014; Dyba, 2017).

Tabela 2. Klastry wybrane do analizy - porównanie

\begin{tabular}{|l|l|l|}
\hline & \multicolumn{1}{|c|}{ Livenza } & \multicolumn{1}{|c|}{ Kępno } \\
\hline Początki & $\begin{array}{l}\text { Lata pięćdziesiąte i sześćdziesiąte XX } \\
\text { wieku - pierwsze firmy powstały po } \\
\text { drugiej wojnie światowej, największy } \\
\text { rozkwit w latach siedemdziesiątych, } \\
\text { osiemdziesiątych i dziewięćdziesiątych }\end{array}$ & $\begin{array}{l}\text { Lata osiemdziesiąte XX wieku, największe } \\
\text { istniejące dziś firmy powstały na } \\
\text { początku lat dziewięćdziesiątych }\end{array}$ \\
\hline Faza cyklu życia & Dojrzały & Rosnący \\
\hline $\begin{array}{l}\text { Liczba firm i jej } \\
\text { dynamika }\end{array}$ & 413; spadek w latach 2009-2017 & $\begin{array}{l}\text { Około 380; nieznaczny wzrost w latach } \\
\text { 2009-2017 }\end{array}$ \\
\hline $\begin{array}{l}\text { Cechy } \\
\text { charakterystyczne }\end{array}$ & $\begin{array}{l}\text { Klaster rozpoznawany w branży } \\
\text { meblarskiej z powodu produkcji } \\
\text { stylowych i nowoczesnych mebli (firmy } \\
\text { wyznaczają trendy) }\end{array}$ & $\begin{array}{l}\text { Największe firmy produkują meble } \\
\text { ze średniej i niższej półki cenowej na } \\
\text { eksport (i często sprzedają je pod marką } \\
\text { inną niż swoja) }\end{array}$ \\
\hline
\end{tabular}

Źródło: opracowanie własne

Dodać należy, że Livenza to klaster położony na obszarze znanym w literaturze jako Trzecie Włochy (Terzia Italia), charakteryzującym się funkcjonowaniem wielu małych i średnich przedsiębiorstw, często rodzinnych, działających w tradycyjnych sektorach gospodarki. Dzięki szczególnemu kapitałowi społecznemu, opartemu na relacjach 
międzyludzkich i zaufaniu, w latach siedemdziesiątych i osiemdziesiątych XX wieku firmy te zdołały tam osiągnąć duży wzrost (Stryjakiewicz, 1999; Becattini, Bellandi, De Propris, 2009). Od tego czasu obszar ten przeszedł jednak sporą ewolucję, część klastrów uległa odmłodzeniu i rozwinięciu, część (w tym Livenza) utrzymuje swoją wielkość i pozycję, inne z kolei mają problemy, a ich wielkość mierzona zatrudnieniem i produkcją maleje (De Marchi, Grandinetti, 2014; Bellandi, De Propris, 2015). Z kolei polskie klastry meblarskie są jeszcze stosunkowo słabo poznane (Dyba, 2017).

Procedura badania źródeł wiedzy wykorzystywanych przez firmy klastrowe składała się z kilku etapów. W pierwszym etapie, na podstawie literatury przedmiotu oraz konsultacji wśród przedstawicieli sektora meblarskiego w obu krajach, utworzono listę źródeł nowej wiedzy, z których mogą korzystać firmy klastrowe (tabela 3). Jest wśród nich kategoria źródeł wewnętrznych: kreatywność i pomysły kadry zarządzającej lub pracowników, oraz 13 źródeł zewnętrznych. Źródła zewnętrzne podzielone zostały na trzy kategorie: 1) tradycyjne mechanizmy przepływu wiedzy pomiędzy firmami, 2) sposoby profesjonalnego pozyskiwania wiedzy spoza firmy oraz 3) media i wydarzenia.

Tabela 3. Rodzaje źródeł nowej wiedzy możliwe do wykorzystania przez firmy w klastrze

\begin{tabular}{|c|c|c|}
\hline Lp. & Źródło nowej wiedzy & Grupa \\
\hline $\mathrm{X} 1$ & $\begin{array}{l}\text { Węwnętrzne tworzenie wiedzy (kreatywność oraz pomysły } \\
\text { właściciela i pracowników) }\end{array}$ & źródła wewnętrzne \\
\hline $\mathrm{X} 2$ & $\begin{array}{l}\text { Współpraca z podobnymi firmami branżowymi oraz } \\
\text { dostawcami i podwykonawcami zlokalizowanymi w pobliżu }\end{array}$ & \multirow{4}{*}{$\begin{array}{l}\text { tradycyjne mechanizmy } \\
\text { przepływu wiedzy pomiędzy } \\
\text { firmami w klastrze }\end{array}$} \\
\hline $\mathrm{X} 3$ & $\begin{array}{l}\text { Rozmowy, nieformalne kontakty z przedstawicielami innych } \\
\text { firm }\end{array}$ & \\
\hline $\mathrm{X} 4$ & $\begin{array}{l}\text { Porównania z ofertą i funkcjonowaniem innych, podobnych } \\
\text { firm branżowych zlokalizowanych w okolicy }\end{array}$ & \\
\hline $\mathrm{X} 5$ & Nowi pracownicy & \\
\hline $\mathrm{X} 6$ & Doradztwo i szkolenia zewnętrznych firm konsultingowych & \multirow{6}{*}{$\begin{array}{l}\text { sposoby profesjonalnego } \\
\text { pozyskiwania wiedzy od } \\
\text { podmiotów zewnętrznych }\end{array}$} \\
\hline $\mathrm{X} 7$ & $\begin{array}{l}\text { Oferty przesyłane przez firmy zewnętrzne lub prezentowane } \\
\text { przez przedstawicieli handlowych firm }\end{array}$ & \\
\hline $\mathrm{X} 8$ & Współpraca z uniwersytetami i instytucjami badawczymi & \\
\hline $\mathrm{X} 9$ & $\begin{array}{l}\text { Wydarzenia lub działania organizowane przez izby handlowe, } \\
\text { agencje rozwoju regionalnego i inne instytucje publiczne }\end{array}$ & \\
\hline $\mathrm{X} 10$ & $\begin{array}{l}\text { Wydarzenia lub działania organizacji non profit , np. } \\
\text { stowarzyszeń, instytucji branżowych }\end{array}$ & \\
\hline $\mathrm{X} 11$ & Badania opinii i satysfakcji klientów & \\
\hline $\mathrm{X} 12$ & Uczestnictwo w targach i wydarzeniach branżowych & \multirow{3}{*}{ media i wydarzenia } \\
\hline $\mathrm{X} 13$ & Specjalistyczna prasa branżowa, książki tematyczne & \\
\hline $\mathrm{X} 14$ & Wyszukiwarki i strony internetowe & \\
\hline
\end{tabular}

Źródło: opracowanie własne

Pierwsza z grup obejmuje zarówno formalne, jak i nieformalne mechanizmy wymiany wiedzy pomiędzy podobnymi firmami, znane w literaturze jako tradycyjnie zachodzące w klastrach (por. Camuffo, Grandinetti, 2011). Druga grupa to sposoby profesjonalnego pozyskiwania wiedzy od podmiotów zewnętrznych, takich jak specjalistyczne firmy i instytucje otoczenia biznesu oraz badania opinii i satysfakcji klientów (por. Kang, Kang, 2009; De Marchi, Grandinetti, 2014; Dyba, 2016). Trzecia grupa to 
różnego rodzaju wydarzenia targowe i branżowe, prasa specjalistyczna oraz internet, który znacznie ułatwia poszukiwanie nowej wiedzy (Bellandi, De Propris, 2015).

W kolejnym etapie procedury badawczej w 2017 roku przeprowadzone zostały badania ankietowe wśród przedstawicieli kadry zarządzającej przedsiębiorstw położonych na obszarze obu klastrów. Ankietowanie odbyło się poprzez zaproszenie do wypełnienia elektronicznego formularza, a w przypadku braku odpowiedzi - również telefonicznie. Do udziału w badaniu zaproszone zostały wszystkie firmy meblarskie badanych klastrów, jednak ostatecznie pozytywnie odpowiedziała różna liczba firm: 213 z Livenzy (około $1 \frac{1}{2}$ populacji) i 100 z kępińskiego zagłębia meblowego (około $1 / 4$ populacji). Niestety, wiele firm z Kępna i okolic odmówiło wzięcia udziału w badaniu (argumentując to m.in. brakiem czasu, niechęcią dzielenia się informacjami lub brakiem wyraźnych korzyści dla firmy). Ta różnica w chęci uczestnictwa w badaniu ankietowym również może potwierdzać różnice stopnia dojrzałości obu klastrów.

W jednym z pytań respondenci zostali poproszeni o ocenę (w skali od 1 do 5) przydatności wyszczególnionych powyżej 14 źródeł wiedzy w swojej codziennej działalności. Wiedza została na początku ankiety zdefiniowana jako wszystkie informacje technologiczne i biznesowe wykorzystywane w firmie do podejmowania decyzji. Podano też skalę ocen: 5 - oznaczało informacje szczególnie przydatne, 4 - przydatne, 3 - średnio przydatne, 2 - raczej nieprzydatne, 1 - zupełnie nieprzydatne. Następnie zostały wyliczone podstawowe charakterystyki statystyczne dla uzyskanych wyników: średnia arytmetyczna (Śr.), odchylenie standardowe (O), mediana (M) i dominanta (D). Obliczenie średniej (dla wyników na skali porządkowej) było możliwe, gdyż wyniki wykazywały rozkład zbliżony do normalnego. Przeprowadzono również statystyczną analizę wariancji, której celem była ocena, dla których źródeł wiedzy różnice pomiędzy polskim i włoskim klastrem były statystycznie istotne.

\section{WYNIKI BADAŃ: ŹRÓDŁA WIEDZY WYKORZYSTYWANE PRZEZ FIRMY W KLASTRACH MEBLARSKICH W LIVENZIE I KĘPNIE}

W tabeli 4 przedstawione zostały wyniki badań ankietowych przeprowadzonych w klastrach meblarskich w Livenzie i Kępnie. Dla każdego ze studiów przypadku zestawienie zawiera wartości statystyczne obliczone dla 14 uwzględnionych w badaniu źródeł wiedzy, a także pozycję (od 1 do 14), jakie każde źródło uzyskało w zakresie przydatności dla firm. Dodatkowo ostatnia kolumna zawiera informację, które ze źródeł wiedzy wykazują istotną statystycznie różnicę pomiędzy dwoma klastrami.

Wyniki badania pozwalają na sformułowanie kilku wniosków dotyczących podobieństw w pozyskiwaniu wiedzy przez firmy w obu klastrach. Rozmówcy postrzegają siebie lub swoich współpracowników (a więc zasoby wewnętrzne, X1) jako najważniejsze źródło wiedzy: w obu przypadkach dominanta dla tej kategorii wynosi 5. W Kępnie średnia ocena tego źródła jest najwyższa spośród wszystkich - ma wartość powyżej 4, a w Livenzie znajduje się na wysokim, trzecim miejscu. Również wysoka średnia użyteczność została przypisana w obu klastrach do źródeł w grupie „media i wydarzenia”, przede wszystkim do udziału w targach i wydarzeniach branżowych (X12) oraz wyszukiwarek i stron internetowych (X14). Jednocześnie w obu klastrach dla większości źródeł wiedzy dominanta wynosiła 1, tzn. większość respondentów oceniła jako przydatne tylko nieliczne kategorie, a inne nie były w ogóle używane lub były wykorzystywane rzadko. 


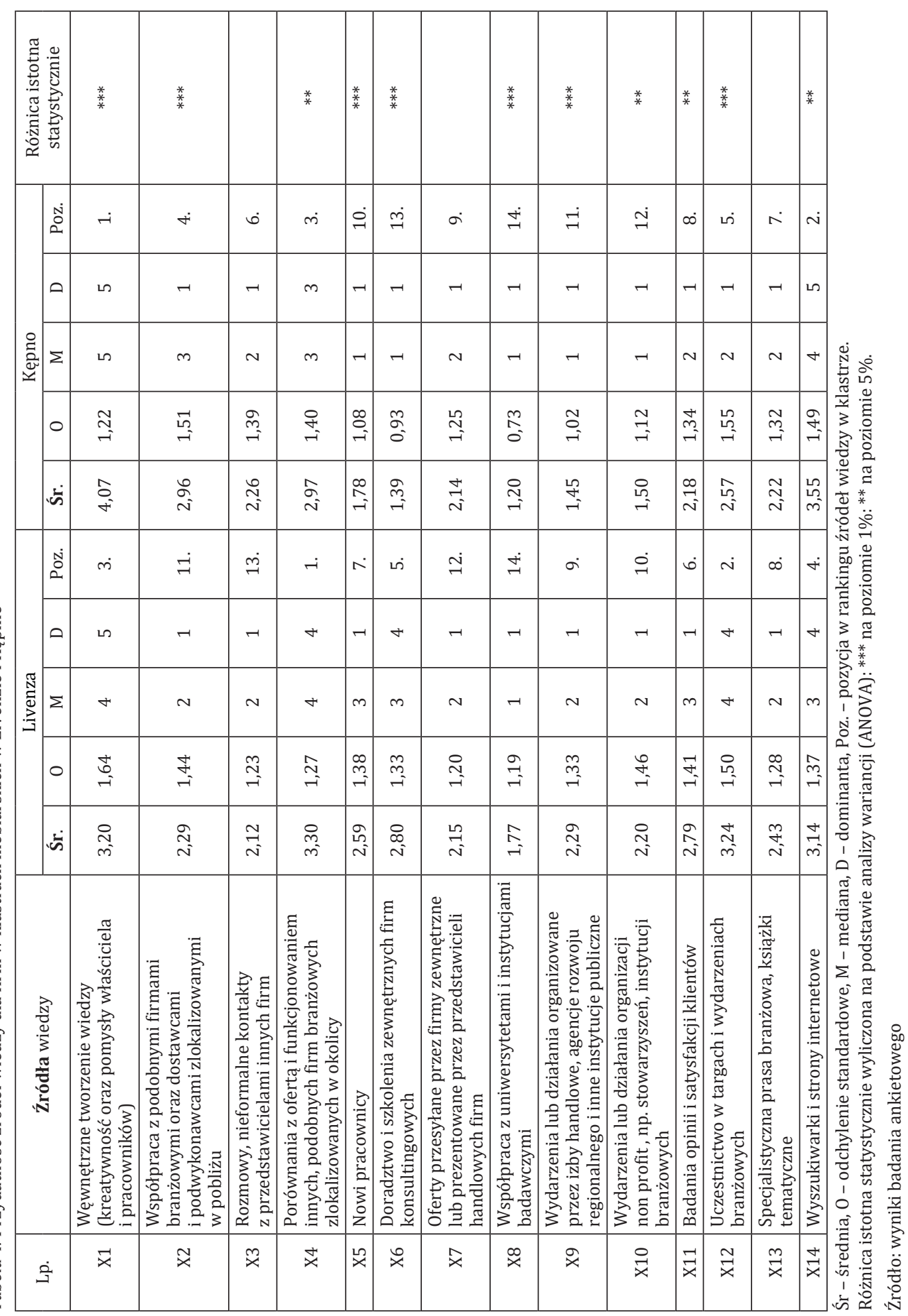


W odniesieniu do obu studiów przypadku zaobserwowano również kilka znaczących, generalnych różnic w zakresie przydatnych źródeł wiedzy ujmowanych całościowo. Średnia wartość oraz dominanta dla wszystkich źródeł wiedzy (odpowiedzi dla wszystkich kategorii) w Livenzie wyniosły odpowiednio 2,58 i 3, a w Kępnie 2,30 i 2. Statystyczne charakterystyki odpowiedzi w dojrzalszym klastrze Livenzy były więc wyższe niż w Kępnie - klastrze młodszym i rosnącym. Co więcej, w Livenzie pięć źródeł miało dominującą wartość 5 lub 4, w Kępnie - tylko dwa. W Livenzie mediana dla wszystkich odpowiedzi wynosiła 3, w Kępnie - 2. Dowodzi to, że w firmach włoskiego klastra stosuje się bardziej zróżnicowane źródła wiedzy, ponieważ źródła łatwo dostępne nie są wystarczające dla dalszego wzrostu firm.

Analizując każdą z trzech wydzielonych grup źródeł wiedzy osobno, najmniejsze różnice pomiędzy dwoma klastrami zaobserwowano w grupie trzeciej - „media i wydarzenia”. W obu przypadkach badanie wykazało wysoką przydatność jako źródła wiedzy takich kategorii, jak: uczestnictwo w targach i wydarzeniach branżowych (X12) oraz wyszukiwarki i strony internetowe (X14, ciągle rozwijane i ulepszane pod względem łatwości wykorzystywania).

W grupie pierwszej - „tradycyjne mechanizmy przepływów wiedzy w klastrach” - najwyższe odpowiedzi w obu klastrach uzyskały porównania z innymi podobnymi firmami (X4): źródło to osiągnęło pierwsze miejsce w Livenzie i trzecie w Kępnie. Wydaje się, że bliskość innych podobnych firm działa mobilizująco: śledzenie ich funkcjonowania ma na celu pozostawanie na bieżąco w zakresie wiedzy branżowej. Dwie pozostałe kategorie: współpraca z innymi firmami i dostawcami (X2) oraz rozmowy i nieformalne kontakty z podobnymi firmami (X3) zostały sklasyfikowane w środku rankingu przydatności źródeł wiedzy w Kępnie, a jednocześnie pod koniec rankingu w Livenzie. Sugeruje to, że w dojrzałym klastrze firmy boją się konkurentów i stąd unikają możliwości ujawniania swojej wiedzy. Dodać jednak należy, że średnia przydatność obu kategorii źródeł wiedzy (X2 i X3) była niska w obu przypadkach, a niewielkie różnice (wyższe wartości dla klastra w Kępnie) były statystycznie nieznaczące.

Wreszcie w grupie drugiej - „sposoby profesjonalnego pozyskiwania wiedzy od podmiotów zewnętrznych" największe różnice w przydatności źródeł wiedzy dla firm w klastrach w Livenzie i Kępnie zaobserwowano dla takich kategorii jak: doradztwo zewnętrzne lub szkolenia (X6) oraz wydarzenia lub działania organizowane przez izby handlowe, agencje rozwoju regionalnego i inne instytucje publiczne (X9). Obie kategorie są oceniane jako ważne w klastrze w Livenzy, ale nie w klastrze z Kępna. Sugeruje to, że środowisko biznesowe (wyposażenie instytucjonalne) jest silniej rozwinięte we Włoszech i tworzy więcej możliwości skorzystania z profesjonalnych źródeł wiedzy. Co ciekawe, większość źródeł wiedzy w tej grupie (X6, X9, ale także X8 - współpraca z uniwersytetami i instytucjami badawczymi oraz X10 - działalność organizacji branżowych) wykazała statystycznie istotne różnice między klastrami z Polski i Włoch określone poprzez statystyczną analizę wariancji. Wszystkie te źródła osiągnęły większe wartości w Livenzie (choć przyznać należy, że średnie i dominujące wartości dla niektórych z tych kategorii były ogólnie niskie). Pozwala to pozytywnie potwierdzić hipotezę badawczą, zgodnie z którą w dojrzalszych klastrach - w porównaniu z klastrami rosnącymi - przedstawiciele firm przypisują większe znaczenie profesjonalnym źródłom wiedzy. Wydaje się zarazem, że im dojrzalszy klaster, tym mniejsza jest rola „lokalnego gwaru”, a większa „globalnych kanałów” spoza klastra, transportujących wiedzę do firm klastrowych. 


\section{PodsumowANIE}

Badanie pozwoliło wykazać podobieństwa, ale przede wszystkim różnice w zakresie pozyskiwania nowej wiedzy w klastrach meblarskich znajdujących się w różnych fazach cyklu życia. Ankietowani przedstawiciele firm za niezwykle ważne źródło nowej wiedzy, prowadzącej w konsekwencji do innowacji i wzrostu, uznali kreatywność i pomysły pracowników. Wynik ten odzwierciedla modele zarządzania wiedzą podkreślające, że tworzenie nowej wiedzy jest podstawowym etapem tego zarządzania, wymagającym aktywnego zaangażowania personelu firmy. Przy pozyskiwaniu wiedzy zewnętrznej istotne są również zdolności i intuicja w tym zakresie pracowników firmy (Davenport, Prusak, 1998; Probst, Raub, Romhardt, 2000). Badanie pozwoliło potwierdzić, że środowisko klastrowe stwarza dodatkowe możliwości korzystania z zewnętrznych źródeł wiedzy, takie jak formalna współpraca z innymi firmami lub nieformalne kontakty $\mathrm{z}$ innymi interesariuszami. Ze względu na konkurencję firmy korzystają z nich jednak w sposób ostrożny. Co ciekawe, rozmowy i nieformalne kontakty z przedstawicielami innych firm, powszechnie postrzegane jako jedna z najważniejszych cech klastrów (w tym na obszarze Trzecich Włoch, znanych z długotrwałych relacji i kapitału społecznego), w obu badanych przypadkach okazały się rzadkie i mało znaczące. Należy jednak mieć na uwadze, że specyfika produkcji mebli jest inna niż klastrów ICT, najczęściej opisywanych w tym kontekście w literaturze (Saxenian,1994; Storper, Venables, 2004; Swann, 2009). Badanie wykazało, że wśród źródeł wiedzy w klastrach meblarskich szeroko rozpowszechnione jest porównywanie się do innych, podobnych firm zlokalizowanych w pobliżu; przedstawiciele firm klastrowych cenią ten sposób uzyskiwania informacji technologicznych i biznesowych. Z kolei konkurencja wymusza na nich korzystanie $\mathrm{z}$ wiedzy podmiotów zewnętrznych, $\mathrm{w}$ tym często profesjonalnych, również takich, które znajdują się poza klastrem (co potwierdza model tworzenia i rozpowszechniania wiedzy w klastrze autorstwa H. Bathelta, A. Malmberga i P. Maskella, 2004).

Z przeprowadzonego badania wynika, że $w$ dojrzałych klastrach, takich jak klaster meblarski w Livenzie, firmy częściej korzystają z profesjonalnych źródeł wiedzy niż w klastrach rosnących, którego przykładem jest klaster meblarski w Kępnie. Zaobserwowano istotne statystycznie różnice $w$ takich kategoriach źródeł wiedzy, jak: korzystanie z doradztwa i szkoleń zewnętrznych firm konsultingowych, współpraca z uniwersytetami i placówkami naukowo-badawczymi, a także szkolenia i działania instytucji publicznych oraz organizacji non profit. Źródła te są częściej wykorzystywane w Livenzie niż w Kępnie, co świadczy o tym, że silniej zaawansowane środowisko biznesowe, z instytucjami świadczącymi usługi dla firm klastrowych, stwarza większe możliwości pozyskiwania zewnętrznej wiedzy.

W dojrzałym klastrze w Livenzie za przydatne traktowane są również takie źródła wiedzy, jak nowi pracownicy czy badania satysfakcji klientów - pozycje uznawane za raczej nieprzydatne w rosnącym klastrze z Kępna. Nowo zatrudnieni pracownicy (zwłaszcza menedżerowie) wnoszą do firmy nową wiedzę, która w sytuacji rosnącej konkurencji na ograniczonym rynku może stanowić źródło przewagi nad innymi. Jeśli chodzi o klientów, to należy pamiętać, że przewaga polskich producentów mebli leży w dużej mierze w taniej, masowej produkcji zorientowanej na eksport, a siłą ich włoskich odpowiedników są stylowe, dobrze zaprojektowane produkty dla bardziej wymagających klientów, z którymi bliski kontakt wydaje się konieczny. Uwzględnienie 
oczekiwań klientów zyskuje na znaczeniu dopiero po pewnym czasie, na konkurencyjnym rynku.

Przeprowadzone badanie wzbogaca nasze rozumienie roli wiedzy w różnych fazach cyklu życia klastra, dodając do dotychczasowych ustaleń (Bergman, 2008; Menzel, Fornahl, 2010) wnioski dotyczące zmiany znaczenia różnych źródeł wiedzy wraz z dojrzewaniem klastra. Jego wyniki mogą stanowić również ważną wytyczną dla instytucji otoczenia biznesu oraz władz regionalnych. W zależności od faz cyklu życia klastrów znajdujących się na danym obszarze i specyfiki działających w nich firm powinno się tworzyć adekwatne możliwości dostępu do najbardziej pożądanych przez nie, przydatnych źródeł wiedzy.

\section{Literatura \\ References}

Abernathy, W.J., Utterback, J.M. (1978). Patterns of industrial innovation. Technology Review, 80.

Audretsch, D.B., Feldman, M.P. (1996). Inovative clusters and the industry life cycle. Review of Industrial Organisation, 11, 253-273.

Bathelt, H., Malmberg, A., Maskell, P. (2004). Clusters and knowledge: local buzz, global pipelines and the process of knowledge creation. Progress in Human Geography, 28, 31-56.

Becattini, G., Bellandi, M., De Propris, L. (red.) (2009). A handbook of industrial districts. Cheltenham: Edward Elgar Publishing.

Bellandi, M., De Propris, L. (2015). Three generations of industrial districts. Journal of Regional Research - Investigaciones Regionales, 32, 75-87.

Belussi, F., Sedita, S. (2012). Industrial districts as open learning systems: combining emergent and deliberate knowledge structures. Regional Studies, 46(2), 165-184.

Bergman, E.M. (2008). Cluster life-cycles: An emerging synthesis. W: C. Karlsson (red.). Handbook of Research on Cluster Theory. Cheltenham: Edward Elgar Publishing, 114-132.

Boschma, R.A., Ter Wal, A.L. (2007). Knowledge networks and innovative performance in an industrial district: The case of a footwear district in the South of Italy. Industry and Innovation, 14, 177-199.

Buciuni, G., Corò, G., Micelli, S. (2014). Rethinking the role of manufacturing in global value chains: an international comparative study in the furniture industry. Industrial and Corporate Change, 23(4), 967-996.

Bukowitz, W.R., Williams, R.L. (2000). The knowledge management fieldbook. London: Prentice Hall.

Camuffo, A., Grandinetti, R. (2011). Italian industrial districts as cognitive systems: Are they still reproducible? Entrepreneurship \& Regional Development, 23(9-10), 815-852.

Chojnicki, Z., Czyż, T. (2006). Aspekty regionalne gospodarki opartej na wiedzy w Polsce. Poznań: Bogucki Wydawnictwo Naukowe.

Cluster Observatory (2018, 20 listopada). Pozyskano z www.clusterobservatory.eu

Davenport, T.H., Prusak, L. (1998). Working knowledge. How organizations manage what they know. Boston: Harvard Business School Press.

De Marchi, V., Di Maria, E., Gereffi, G. (red.) (2017). Local clusters in Global Value Chains. Linking actors and territories through manufacturing and innovation. Abingdon-on-Thames: Routledge.

De Marchi, V., Grandinetti, R. (2014). Industrial districts and the collapse of the Marshallian model: looking at the Italian experience. Competition \& Change, 18(1), 70-87.

Dyba, W. (2016). Przepływy wiedzy $w$ organizacjach klastrowych w Polsce zachodniej. Poznań: Bogucki Wydawnictwo Naukowe.

Dyba, W. (2017). Klastry meblarskie na tle struktury przestrzennej przemysłu meblarskiego w Polsce. Prace Komisji Geografii Przemysłu Polskiego Towarzystwa Geograficznego, 31(1), 38-51. 
Fornahl, D., Hassink, R., Menzel, M.P. (2015). Broadening Our Knowledge on Cluster Evolution. European Planning Studies, 23, 1921-1931.

Giuliani, E. (2007). The Selective Nature of Knowledge Networks in Clusters: Evidence from the Wine Industry. Journal of Economic Geography, 7(2), 139-168.

Gorynia, M., Jankowska, B. (2008). Klastry a międzynarodowa konkurencyjność i internacjonalizacja przedsiębiorstwa. Warszawa: Wydawnictwo Difin.

Grant, R. (2002). Towards a Knowledge Based Theory of the Firm. Strategic Management Journal, $17,109-122$.

Hoffmann, V.E., Belussi, F., Martínez-Fernández, M.T., Reyes E. Jr (2017). United we stand, divided we fall? Clustered firms' relationships after the 2008 crisis. Entrepreneurship \& Regional Development, 29(7-8), 735-758.

Jankowska, B. (2012). Koopetycja $w$ klastrach kreatywnych. Przyczynek do teorii regulacji $w$ gospodarce rynkowej. Poznań: Wydawnictwo Uniwersytetu Ekonomicznego w Poznaniu.

Jemielniak, D., Koźmiński, A.K. (2008). Zarządzanie wiedzq - podręcznik akademicki. Warszawa: Wydawnictwo Akademickie i Profesjonalne.

Kang, K.H., Kang, J. (2009). How do firms source external knowledge for innovation? International Journal of Innovation Management, 13(1), 1-17.

Kogut, B., Zander, U. (1992). Knowledge of the firm, combinative capabilities and the replication of technology. Organization Studies, 3, 386-397.

Kukliński, A. (red.) (2001). Gospodarka oparta na wiedzy. Wyzwanie dla Polski XXI wieku. Warszawa: Komitet Badań Naukowych.

Li, P. (2018). A tale of two clusters: knowledge and emergence. Entrepreneurship \& Regional Development, 30(7-8), 1-26.

Marshall, A. (1890). Principles of economics. London: Macmillan.

Martin, R., Moodysson, J. (2011). Innovation in symbolic industries: the geography and organisation of knowledge sourcing. European Planning Studies, 19(7), 1183-1203.

Martin, R., Sunley, P. (2011). Conceptualizing cluster evolution: beyond the life cycle model? Regional Studies, 45, 1299-1318.

Maskell, P., Kebir, L. (2005). What qualifies as a cluster theory? Copenhagen: Department of Industrial Economics and Strategy, Copenhagen Business School.

Maskell, P., Malmberg, A. (2007). Myopia, knowledge development and cluster evolution. Journal of Economic Geography, 7(5), 603-618.

Menzel, M.P., Fornahl, D. (2010). Cluster life cycles - dimensions and rationales of cluster evolution. Industrial and Corporate Change, 19(1), 205-238.

Micek, G. (2017). Bliskość geograficzna przedsiębiorstw zaawansowanego przemysłu i usług a przepływy wiedzy. Kraków: Instytut Geografii i Gospodarki Przestrzennej Uniwersytetu Jagiellońskiego.

Nonaka, I. (1994). A dynamic theory of organizational knowledge creation. Organization Science, $5(1), 14-37$.

OECD (1996). The Knowledge-based economy. General distribution OECD/GD(96)102.

Ortega-Colomer, F.J., Molina-Morales, F.X., Fernandez de Lucio, I. (2016). Discussing the concepts of cluster and industrial district. Journal of Technology Management \& Innovation, 11(2), 139-147.

Perechuda, K. (red.) (1998). Zarządzanie wiedzą w przedsiębiorstwie. Warszawa: Wydawnictwo Naukowe PWN.

Porter, M.E. (1980). Competitive strategy: techniques for analyzing industries and competitors. New York: Free Press.

Porter, M.E. (1990). The competitive advantage of nations. New York: Free Press.

Porter, M.E. (1998). Clusters and the new economics of competition. Harvard Business Review, 76, 77-90.

Porter, M.E., Ketels, C. (2009). Clusters and industrial districts: Common roots, different perspectives. In: G. Becattini, M. Bellandi, L. De Propris (red.). A Handbook of Industrial Districts. Cheltenham, Northampton: Edward Elgar, 172-184.

Probst, G.J.B., Raub, S., Romhardt, K. (2000). Managing knowledge: building blocks for success. Chichester: Wiley. 
Pyke, F., Becattini, G., Sengenberger, W. (red.) (1990). Industrial districts and inter-firm co-operation in Italy. International Institute for Labour Studies.

Saxenian, A. (1994). Regional advantage: culture and competition in Silicon Valley and Route 128. Cambridge, MA: Harvard University Press.

Schrader, S. (1991). Informal technology transfer between firms. Cooperation through information trading. Research Policy, 20, 153-170.

Storper, M., Venables, A.J. (2004). Buzz: Face-to-face contact and the urban economy. Journal of Economic Geography, 4, 351-370.

Stough R.R. (2015). Cluster life-cycles, entrepreneurship and regional economic development with a case study of the Korean shipbuilding cluster. W: P. Nijkamp, A. Rose, K. Kourtit (red.). Regional Science Matters. Heidelberg: Springer International Publishing.

Stryjakiewicz, T. (1999). Adaptacja przestrzenna przemysłu w Polsce $w$ warunkach transformacji. Poznań: Wydawnictwo Naukowe Uniwersytetu im. Adama Mickiewicza.

Swann, G.M.P. (2009). How firms achieve innovation: clusters and networks. W: G.M.P. Swann. The economics of innovation. Cheltenham, Northampton: Edward Elgar, 147-172.

Toffler, A. (1990). Powershift: Knowledge, Wealth and Violence at the Edge of 21st Century. New York: Bantam Books.

Toffler, A. (2006). Trzecia fala. Poznań: Wydawnictwo Kurpisz.

Trippl, M., Tödtling, F., Lengauer, L. (2009). Knowledge Sourcing Beyond Buzz and Pipelines: Evidence from the Vienna Software Sector. Economic Geography, 85(4), 443-462.

Tsai, D. (2006). Knowledge spillovers and high-technology clustering: evidence from Taiwan's Hsinchu science-based industrial park. Contemporary Economic Policy, 23(1), 116-128.

Vernon, R. (1966). International investment and international trade in the product cycle. Quarterly Journal of Economics, 80, 190-207.

Wiig, K. (1997). Knowledge management: an introduction and perspective. Journal of Knowledge Management, 1(1), 6-14.

You, J., Wilkinson, F. (1994). Competition and co-operation: toward understanding industrial districts. Review of Political Economy, 6(3), 259-278.

Artykuł powstał w ramach realizacji grantu NCN nr 2015/17/N/HS4/00205, finansowanego ze środków Narodowego Centrum Nauki.

Wojciech Dyba, dr. inż., adiunkt w Instytucie Geografii Społeczno-Ekonomicznej i Gospodarki Przestrzennej. Stypendysta Fundacji UAM (2015) oraz Fundacji na rzecz Nauki Polskiej (2018). Odbył staż zagraniczny na Uniwersytecie Padewskim (2018). Główne zainteresowania naukowe: geografia ekonomiczna (klastry, lokalizacja działalności gospodarczej, innowacyjność, globalizacja) oraz rozwój regionalny i lokalny (w tym w szczególności strategie rozwoju regionalnego i lokalnego oraz koncepcje zagospodarowania przestrzennego).

Wojciech Dyba, PhD, assistant professor in the Institute of Socio-Economic Geography and Spatial Management of Adam Mickiewicz University in Poznań. He received scholarships from the Adam Mickiewicz Foundation (2015) and the Foundation for Polish Science (2018). He was a fellow at the University of Padua (2018). His main research interests include: economic geography (clusters, location of economic activity, innovativeness, globalisation), as well as regional and local development (strategies for development, spatial development plans).

\section{ORCID: 0000-0003-1554-5938}

\section{Adres/address:}

Uniwersytet im. Adama Mickiewicza w Poznaniu Instytut Geografii Społeczno-Ekonomicznej i Gospodarki Przestrzennej ul. Bogumiła Krygowskiego 10, 61-680 Poznań, Polska e-mail: wojtek@amu.edu.pl

Tadeusz Stryjakiewicz, prof. dr hab., profesor zwyczajny w Instytucie Geografii Społeczno-Ekonomicznej i Gospodarki Przestrzennej, kierownik Zakładu Polityki Regionalnej i Integracji Europejskiej na Uniwersytecie im. Adama Mickiewicza w Poznaniu. Stypendysta Fundacji na rzecz Nauki Polskiej i Fundacji Volkswagena. Odbył staże zagraniczne m.in. na Uniwersytecie im. Johanna Wolfganga Goethego we Frankfurcie nad 
Menem oraz w Szkole Studiów Slawistycznych i Wschodnioeuropejskich University College w Londynie. Wykładowca wizytujący na Uniwersytecie im. Erazma w Rotterdamie. Główne zainteresowania naukowe: geografia ekonomiczna, lokalizacja działalności gospodarczej, rozwój regionalny i lokalny, organizacja i dynamika przestrzeni społeczno-ekonomicznej (w tym rozwój sektora kreatywnego). Uczestnik kilkunastu krajowych i międzynarodowych projektów badawczych; autor lub współautor 280 publikacji naukowych oraz licznych ekspertyz i raportów. Członek Centralnej Komisji ds. Stopni i Tytułów oraz wielu rad i stowarzyszeń naukowych.

Tadeusz Stryjakiewicz, profesor, head of the Department of Regional Policy and European Integration in the Institute of Socio-Economic Geography and Spatial Management at Adam Mickiewicz University in Poznań. He was a fellow at the Johann Wolfgang Goethe University, Frankfurt am Main, and in the School of Slavonic and East European Studies, University of London. He was a visiting lecturer at the Erasmus University in Rotterdam. His main research interests include: economic geography, location of economic activity, regional and local development, organisation and dynamics of socio-economic space (including creative industries). He has participated in several national and international research projects, authored (or co-authored) 280 research publications and many expert reports. He is a member of the Central Commission for Scientific Degrees and Titles and of many research councils and institutions.

ORCID: 0000-0002-3740-7301

\section{Adres/address:}

Uniwersytet im. Adama Mickiewicza w Poznaniu Instytut Geografii Społeczno-Ekonomicznej i Gospodarki Przestrzennej ul. Bogumiła Krygowskiego 10, 61-680 Poznań, Polska

e-mail: tadek@amu.edu.pl 